\title{
Work-Life Balance Issues Encountered by Working Women in Higher Education Sector
}

\author{
Dr. Sonia Delrose Noronha ${ }^{1} \&$ Dr. P. S. Aithal ${ }^{2}$
}

1,2 College of Management \& Commerce, Srinivas University, Mangaluru - 575001, Karnataka, India.

\begin{abstract}
Education, Exposure, Awareness, and, Changes in the lifestyle has been successful in bringing women out of the four walls of domestic confinement into the world of earning, confidence, and selfreliance. Achievements of women in every field are noticeable bringing laurels to womanhood. Along with this that goes unnoticeable are the challenges faced by these women all through their working life. This is a big obstacle for women to function daily and also prove and progress in their careers. This paper studies the level of challenges faced by women teachers in maintaining Work-Life balance with special reference to State Universities of Karnataka. Responses from the sample are used to test the hypotheses that there is an association between Challenges faced and work-life balance. Challenges have been studied under three domains such as Individual factors, Family Factors, and Organizational Factors. For this purpose, 422 Women teachers of State Universities of Karnataka were selected for the study. The study showed that respondents had an overall moderate level of challenges. Results also revealed that there is an association between the challenges and work-life balance. The outcome of the study will help in understanding the challenges faced and its relationship with work-life balance.
\end{abstract}

Keywords: Work-life Balance (WLB); Challenges; State Universities; Self-Reliance

\section{Introduction:}

Work-Life Balance (WLB) includes the interaction between the duties for the paid work with any organization and the unpaid work obligations of the family and self-improvement. Work-Life balance is "the degree to which a person's effectiveness and fulfillment in work and family jobs are compatible with the person's life needs [1]. Work-family balance is characterized as the achievement of jobrelated desires that are arranged and shared between an individual and his or her job-related accomplices in the work and family areas. Work-life has become a significant issue confronted by working women in day to day life. The degree of balance kept up in such manner differs from women to women. Work-Life Balance impacts the basic leadership, efficiency, and managerial limit of a wide range of employees including skilled as well as unskilled employees at all levels. The Economic, social, and demographic factors have seriously affected the individual and professional life of women. The subject WLB picked up force throughout the years with the advancement of women into the corporate world when social desires proceeded with the view that women are obliged significantly to family responsibilities. The stereotyped social stigma that men have the sole right to work outside and the women to take up family care alongside domestic chores have abridged women from exceeding expectations in her concerned profession. Research shows the importance of work-life balance since it is related to the psychological wellbeing of an employee and also brings overall harmony in life. Work-Life Balance as stated by Clark (2008) as contentment and good working at work and home with a minimal role clash [2]. Whereas Parkes and Langford (2008)defined work-life Balance as a person's ability to meet family and work commitment as well as non-work responsibilities and other activities. These definitions for work-life balance indicate creating an 
acceptable situation of work and life [3]. Demographic components like age, pay, Qualification, experience, kind of family and life partner working, affect work-life balance and work-related variables like targets, working hours, expanded advantages and benefits[4]. Darji Mittal in her study has stated the words of Muhammad Ali Jinnah that no nation can achieve the height of glory unless their women are side by side with men[5]. Changing roles of women have contributed in many employment sectors and several aspects of Indian life. Previously male-dominated areas are now occupied with women resulting in spending less time in maintaining domestic requirements. To balance work and family, it becomes necessary to plan a career efficiently. Work-Life Balance is making a profitable work culture to decrease the irregularity caused between the work and different parts of individuals' lives. It is viewed as the blend of fitting work openings, supporting hierarchical frameworks, and steady administration. It makes the correct blend of interest in paid work represented dependent on working conditions with different parts of the individual existence of representatives. In an, all the more by and large held view work-life balance is the adaptable work systems to accomplish an appropriate harmony among Work and Personal Responsibilities. Widespread industrialization and education have increased the challenge and economic sustainability. This has become a pressure factor for all family members to work to increase income. It has been analyzed that working women in Pondicherry face high problem in maintaining work-life balance and that work-life imbalance affects their quality of work-life [6]. Research shows that married working women face more difficulties as compared to others. It is said that married working women cannot significantly contribute to the betterment of their families [7].In this regard, the need to keep up suitable working conditions where representatives could balance work with their individual necessities has become a significant factor for the organizations to retain its proficient workforce and to improve hierarchical profitability.

\section{Literature review:}

The literature review is a framework of all the accessible information on specific research topics available till date. Literature related to work-life balance has been reviewed from various Journals, Books, Doctoral Thesis, and Internet sites.

Table 1: Review of Literature

\begin{tabular}{|c|c|c|}
\hline S.No & Author & Contribution \\
\hline 1 & $\begin{array}{l}\text { Noronha, Sonia; } \\
\text { \&Aithal } \\
\text { P.S.(2019) }\end{array}$ & $\begin{array}{l}\text { Have highlighted the existing study on work-Life balance with relation to } \\
\text { Demographic variables, Family, Work-related variables, Work-family } \\
\text { conflict, Job stress, satisfaction, and Glass ceiling [8]. }\end{array}$ \\
\hline 2 & Martin (2001) & $\begin{array}{l}\text { Say that women in the workplace face mental stress, discriminatory } \\
\text { practices, Sexual Harassment, security, and safety issues [9]. }\end{array}$ \\
\hline 3 & Dube (2001) & $\begin{array}{l}\text { Patriarchal society in India consider women as only homemakers and } \\
\text { sexual objects and is subjected to torture and exploitation [10] }\end{array}$ \\
\hline 4 & Andal, N. (2002) & Women are challenged by inequality in the workforce [11]. \\
\hline 5 & $\begin{array}{l}\text { Delgado } \\
\text { \&Canabal, } \\
(2002)\end{array}$ & $\begin{array}{l}\text { Sexual orientation is viewed as a critical determinant of negative activity } \\
\text { overflow in light of the fact that utilized women are required to do the } \\
\text { obligation regarding family administrations and still have the option to } \\
\text { easily deal with their work jobs [12] }\end{array}$ \\
\hline 6 & $\begin{array}{l}\text { Eagly\& } \quad \text { Carly } \\
(2007)\end{array}$ & $\begin{array}{l}\text { Despite the fact that spouses have taken on more household work than } \\
\text { they did in before ages, this addition for women has been counterbalanced } \\
\text { by "heightening weights for serious child-rearing and the expanding time } \\
\text { requests of most significant level professions"[13] }\end{array}$ \\
\hline 7 & $\begin{array}{l}\text { Noronha, Sonia; } \\
\text { \&Aithal } \\
\text { P.S.(2019) }\end{array}$ & $\begin{array}{l}\text { Have identified various work-life balance initiatives undertaken by } \\
\text { employers in various Indian Organizations [14] }\end{array}$ \\
\hline 8 & $\begin{array}{l}\text { Noronha, Sonia; } \\
\text { \&Aithal P.S. } \\
\text { (2016) }\end{array}$ & $\begin{array}{l}\text { Have studied the existence of the Glass ceiling in Indian Political Scenario } \\
\text { and the conditions required for women to obtain higher positions[15]. }\end{array}$ \\
\hline 9 & Noronha, Sonia; & study has \\
\hline
\end{tabular}




\begin{tabular}{|l|l|l|}
\hline & $\begin{array}{l}\text { \&Aithal P.S. } \\
(2019)\end{array}$ & $\begin{array}{l}\text { demographic factors among women state University faculties of } \\
\text { Karnataka [16] }\end{array}$ \\
\hline 10 & $\begin{array}{l}\text { Noronha, Sonia; } \\
\text { \&Aithal P.S. } \\
(2019)\end{array}$ & $\begin{array}{l}\text { Have made an endeavor to discover the difficulties undergone by } \\
\text { organizations in providing work-life balance measures to employees [17] }\end{array}$ \\
\hline 11 & $\begin{array}{l}\text { Noronha, Sonia; } \\
\text { Et.al. (2017) }\end{array}$ & $\begin{array}{l}\text { Highlighted legal and policy framework to bring WLB and have stated the } \\
\text { benefits of WLB[18] }\end{array}$ \\
\hline
\end{tabular}

3. Objective of the study: To review the challenges faced by working women in maintaining worklife balance.

\section{Methods:}

4.1 Subjects:

422 women teachers of state universities of Karnataka had participated in this study. The inclusion criteria were women teachers with the designation of Professor, Associate Professor and Assistant Professor, married, single, divorced, or widowed with and without children working full time. Men, Non-teaching, Technical, and office staff, and health university has been excluded.27 State universities listed by the University Grants Commission having a domicile in Karnataka are considered [19].

\subsection{Data collection procedure:}

The data is collected from 530 respondents from the sample universities. The entire population is considered for the study. Hence sampling technique is not applicable. When the questionnaires were thoroughly checked, 57 questionnaires were half-filled 51 were not returned and therefore, these questionnaires are excluded from the study. A final 422 sample respondents were included for further analysis. Variables are hypothesized and the relationship is examined by using descriptive statistics, Karl Pearson correlation coefficients, and backward regression analysis.

\subsection{Data analysis:}

The Objective of the study: To review the challenges faced by women in maintaining work-life balance has been studied under three domains such as Individual factors, Family Factors, and Organizational factors. Working women face a lot of challenges and issues all through their working life which is a big struggle for them to function daily and also to progress in their career. This section of the study aims at identifying the challenges faced by women working in state universities of Karnataka in maintaining a work-life balance.

Hypothesis $\mathrm{H}_{1} 1$ : There is a relationship between the Challenges faced by women and Work-Life Balance has been formulated for this purpose. Since there were three types of challenges this hypothesis is divided into sub Hypothesis as:

$\mathrm{H}_{1} 1(\mathrm{a})$ : There is a relationship between challenges due to Individual factors and Work-life Balance.

$\mathrm{H}_{1} 1(\mathrm{~b})$ : There is a relationship between challenges due to Family factors and Work-life Balance.

$\mathrm{H}_{1} 1(\mathrm{c})$ : There is a relationship between challenges due to Organizational factors and Work-life Balance.

The reliability and validity of the questionnaire are examined with a Cronbach alpha coefficient test. Overall the questionnaire has 22 items with 3 variables. A pilot study is carried out with a sample size of 53. The Reliability test was done by using SPSS 20.0 version. From the pilot study, it was found that the scale used in the study is appropriate and reliable with Cronbach's Alpha 0.904. A value of 0.70 and above is the acceptable range and it shows the reliability of the instrument [20]. 
Table 2: Reliability Statistics for Challenges faced by women teachers of State Universities of Karnataka

\begin{tabular}{|l|c|c|}
\hline Challenges & No. of Items & Cronbach's Alpha \\
\hline Individual, Family \& Organizational Factors & 22 & 0.904 \\
\hline
\end{tabular}

Source: Primary

The response was collected for each component by using a 5-point Likert scale ( $1=$ Strongly Disagree, $2=$ Disagree, $3=$ Neutral, $4=$ Agree, and $5=$ Strongly Agree). Karl Pearson Correlation analysis technique was used to know the relationship between the challenges faced and the Work-Life balance. Multiple regression analysis is also used to assess the impact of Individual factors, Family factors, and organizational factors on work-life balance. In regression analysis, the work-life balance is the dependent variable, and challenges such as Individual factors, Family factors, and organizational factors are the independent variables.

\section{Results:}

\subsection{Individual Factors:}

$\mathrm{H}_{1} 1$ (a): There is a relationship between challenges due to Individual factors and Work-life Balance is tested. Numerous investigations have shown the significance of individual factors in deciding the level of the work-life balance of employees.

\section{a. Assessment of Challenges due to Individual factors on Work-life balance:}

Challenges due to Individual factors were measured using 8 questions and these questions were measured on 5-point rating scale strongly Disagree (SD)(1), Disagree(D)(2), Neutral(N)(3), Agree(A)(4), Strongly Agree(SA)(5). Interpretation will be done based on the Mean Value as $<2=S D$, $<3=\mathrm{D},>3 \mathrm{~A}$, and $>4=\mathrm{SA}$. Analysis of the Components of Individual Factors is given below. 
Table 3: Assessment of challenges due to Individual factors on Work-life balance

\begin{tabular}{|c|c|c|c|c|c|c|c|c|c|c|c|c|c|c|}
\hline & \multicolumn{2}{|c|}{ SD } & \multicolumn{2}{|c|}{$\mathbf{D}$} & \multicolumn{2}{|c|}{$\mathbf{N}$} & \multicolumn{2}{|c|}{$\mathbf{A}$} & \multicolumn{2}{|c|}{ SA } & \multicolumn{4}{|c|}{ Total } \\
\hline & Freq & $\%$ & Freq & $\%$ & Freq & $\%$ & Freq & $\%$ & Freq & $\%$ & Count & Mean & SD & Median \\
\hline I do not have authority in taking Economic decisions & 0 & $.0 \%$ & 203 & $48.1 \%$ & 71 & $16.8 \%$ & 134 & $31.8 \%$ & 14 & $3.3 \%$ & 422 & 2.90 & .96 & 3.00 \\
\hline I cannot assist my family in buying fixed assets & 0 & $.0 \%$ & 186 & $44.1 \%$ & 103 & $24.4 \%$ & 104 & $24.6 \%$ & 29 & $6.9 \%$ & 422 & 2.94 & .98 & 3.00 \\
\hline $\begin{array}{l}\text { Repayment of the loan is difficult for me from my } \\
\text { salary package }\end{array}$ & 0 & $.0 \%$ & 129 & $30.6 \%$ & 117 & $27.7 \%$ & 125 & $29.6 \%$ & 51 & $12.1 \%$ & 422 & 3.23 & 1.02 & 3.00 \\
\hline $\begin{array}{l}\text { I do not have significant influence over my spending } \\
\text { for health, recreation and other personal requirements }\end{array}$ & 0 & $.0 \%$ & 174 & $41.2 \%$ & 129 & $30.6 \%$ & 96 & $22.7 \%$ & 23 & $5.5 \%$ & 422 & 2.92 & .92 & 3.00 \\
\hline I am satisfied with the choice of my career & 0 & $.0 \%$ & 248 & $58.8 \%$ & 100 & $23.7 \%$ & 37 & $8.8 \%$ & 37 & $8.8 \%$ & 422 & 2.68 & .96 & 2.00 \\
\hline I am not satisfied with my career success & 0 & $.0 \%$ & 204 & $48.3 \%$ & 66 & $15.6 \%$ & 101 & $23.9 \%$ & 51 & $12.1 \%$ & 422 & 3.00 & 1.10 & 3.00 \\
\hline In most ways, my life is not close to my ideal & 0 & $.0 \%$ & 151 & $35.8 \%$ & 137 & $32.5 \%$ & 90 & $21.3 \%$ & 44 & $10.4 \%$ & 422 & 3.06 & .99 & 3.00 \\
\hline Stress at work is affecting my health & 0 & $.0 \%$ & 101 & $23.9 \%$ & 87 & $20.6 \%$ & 147 & $34.8 \%$ & 87 & $20.6 \%$ & 422 & 3.52 & 1.07 & 4.00 \\
\hline
\end{tabular}

Source: Primary 
Overall respondents disagree that "they do not have authority in taking economic decisions" with Mean and standard deviation $2.90 \pm .96$, "they cannot assist their family in buying fixed assets with Mean and Standard deviation $2.94 \pm .98$, "they do not have significant influence over their spending for health, recreation and other personal requirements" with Mean and Standard deviation $2.92 \pm .92$, and that "they are satisfied with the choice of their career" with Mean and Standard Deviation 2.68 土.96. Overall respondents Agree that "Repayment of the loan is difficult for them from their salary package" with the mean value and standard deviation of $3.23 \pm 1.02$, they are not satisfied with their career success with the Mean and standard deviation of $3.00 \pm 1.10$, that in most ways their life is not close to their ideal with Mean and Standard Deviation $3.06 \pm .99$ and that Stress at work is affecting their Health with Mean and Standard deviation of $3.52 \pm 1.07$

\section{b. Overall Challenges due to Individual Factors}

To measure overall challenges due to individual factors a score was obtained by summating scores of 8 components. The score ranges from $8-40$ and this range is divided equally. The level of challenges due to individual factors is as follows. The score 8-18 challenge is considered to be low; 19-29 level of challenge is moderate and 30-40 level of challenge is high. The analysis is given below:

Table 4: Overall challenges due to Individual Factors

\begin{tabular}{|c|c|c|c|c|}
\hline & Frequency & Percent & Mean & S.D \\
\hline Low & 102 & 24.2 & 24.16 & 6.25 \\
\hline Moderate & 231 & 54.7 & & \\
\hline High & 89 & 21.1 & \\
\hline Total & 422 & 100.0 & & \\
\cline { 1 - 2 } Level of Challenge: $8-\mathbf{4 0}$ & \multicolumn{3}{|c}{ Loderate } \\
\hline 19-18-29 & \multicolumn{3}{|c}{ High } \\
\hline $30-40$ &
\end{tabular}

Source: Primary

$24.2 \%$ had low challenges due to individual factors, $54.7 \%$ had moderate challenges due to individual factors and $21.1 \%$ had high challenges due to individual factors. Overall respondents had a moderate level of challenges due to individual factors with mean and standard deviation score of $24.16 \pm 6.25$

\section{c. Testing the Hypothesis}

Correlation between challenges due to individual factors and work-life balance. To ascertain the relationship between challenges due to individual factors and work-life balance Karl Pearson correlation coefficient was calculated. Hypothesis $\mathrm{H}_{1} 1(\mathrm{a})$ : There is a relationship between challenges due to individual factors and work-life balance is tested.

Table 5: Correlation between challenges due to Individual factors and Work-Life balance

\begin{tabular}{|c|c|c|c|c|}
\hline \multicolumn{5}{|c|}{ Correlations } \\
\hline & & Pearson Correlation & $\bar{p}$ & \\
\hline WLB & Overall Challenge due to Individual Factors & -.229 & .000 & sig \\
\hline
\end{tabular}

Source: Primary

The above table shows that there is a significant negative correlation between challenges due to individual factors and work-life balance with $\mathrm{r}=-.229, \mathrm{p}=.000$ which is $<0.01$. Therefore, hypothesis $\mathrm{H}_{1} 1(\mathrm{a})$ : There is a relationship between challenges due to individual factors, and work-life balance is accepted. So, we conclude that the lesser the challenge higher is the work-life balance. 


\section{d. Regression Analysis: Impact of Individual Factors on Work-Life Balance}

To evaluate the impact of these components on work-life balance backward regression analysis was performed by taking 8 components as the independent variable and work-life balance as the dependent variable and the analysis is given below.

Table 6: Components of Individual factors and Work-Life Balance: Regression Analysis

\begin{tabular}{|c|c|c|c|c|c|c|c|}
\hline & \multicolumn{2}{|c|}{$\begin{array}{l}\text { Unstandardized } \\
\text { Coefficients }\end{array}$} & \multirow{2}{*}{$\begin{array}{c}\begin{array}{c}\text { Standardized } \\
\text { Coefficients }\end{array} \\
\text { Beta } \\
\end{array}$} & \multirow[b]{2}{*}{$\mathrm{t}$} & \multirow[b]{2}{*}{$p$} & \multirow[b]{2}{*}{$\begin{array}{l}\text { Adjusted } \\
\text { RSquare }\end{array}$} & \multirow[b]{2}{*}{$\begin{array}{l}\text { ANOVA } \\
\text { p-value }\end{array}$} \\
\hline & B & $\begin{array}{l}\text { Std. } \\
\text { Error }\end{array}$ & & & & & \\
\hline (Constant) & 35.396 & 1.258 & & 28.140 & .000 & \multirow{7}{*}{.231} & \multirow{7}{*}{.000} \\
\hline $\begin{array}{l}\text { I do not have authority in } \\
\text { taking Economic decisions }\end{array}$ & 1.521 & .393 & .212 & 3.870 & .000 & & \\
\hline $\begin{array}{l}\text { Repayment of the loan is } \\
\text { difficult for me from my } \\
\text { salary package }\end{array}$ & -.989 & .470 & -.146 & -2.105 & .036 & & \\
\hline $\begin{array}{l}\text { I do not have significant } \\
\text { influence over my personal } \\
\text { spending for health, } \\
\text { recreation, and other } \\
\text { personal requirements }\end{array}$ & -2.157 & .544 & -.289 & -3.964 & .000 & & \\
\hline $\begin{array}{l}\text { I am satisfied with the choice } \\
\text { of my career }\end{array}$ & 4.088 & .486 & .469 & 8.412 & .000 & & \\
\hline $\begin{array}{l}\text { I am not Satisfied with my } \\
\text { career success }\end{array}$ & -1.291 & .405 & -.206 & -3.185 & .002 & & \\
\hline $\begin{array}{l}\text { Stress at work is affecting my } \\
\text { health }\end{array}$ & -2.128 & .318 & -.330 & -6.701 & .000 & & \\
\hline
\end{tabular}

Source: Primary source

Among 8 components backward regression analysis resulted in 6 significant components affecting work-life balance. They are "I do not have authority in taking Economic decisions" with $\beta=.212$, "Repayment of the loan is difficult for me from my salary package" with $\beta=-.146$, "I do not have significant influence over my personal spending for health, recreation and other personal requirements with $\beta=-.289$, "I am satisfied with the choice of my career" with $\beta=.469$, "I am not satisfied with my career success "with $\beta=-.206$, "Stress at work is affecting my health "with $\beta=-.330$. Among these "Repayment of the loan is difficult for me from my salary package, I do not have significant influence over my spending for health, recreation, and other personal requirements, I am not Satisfied with my career success, Stress at work is affecting my health" have a negative impact on work-life balance which means these factors lead low work-life balance. Factors such as "I do not have authority in taking Economic decisions and I am satisfied with the choice of my career" have a positive impact on work-life balance which means this leads to higher work-life balance. All these components have a $23.1 \%$ influence on work-life balance.

\subsection{Family Factors}

$\mathrm{H}_{1} 1(\mathrm{~b})$ : There is a relationship between challenges due to Family factors and Work-life Balance is tested here. Changes in the work environment, work culture, rules, and regulations, working conditions, and the requirements a home creates a tremendous pressure on the working women to balance between personal and professional life. With the changes in the work environment, it has become difficult to keep personal life away from professional life. 
a. Assessment of challenges due to Family factors on Work-life balance

Challenges due to Family factors were measured using 8 questions and these questions were measured on 5-point rating scale strongly Disagree (SD) (1), Disagree(D) (2), Neutral(N) (3), Agree(A)(4), Strongly Agree(SA) (5). Interpretation will be done based on the Mean Value as $\angle 2=S D$, $<3=\mathrm{D},>3 \mathrm{~A}$, and $>4=\mathrm{SA}$. Analysis of the Components of Family Factors is given in the table 4.11. 
Table 7: Challenges due to Family factors on Work-life balance

\begin{tabular}{|c|c|c|c|c|c|c|c|c|c|c|c|c|c|c|}
\hline & \multicolumn{2}{|c|}{ SD } & \multicolumn{2}{|c|}{ D } & \multicolumn{2}{|c|}{$\mathbf{N}$} & \multicolumn{2}{|c|}{ A } & \multicolumn{2}{|c|}{ SA } & \multicolumn{4}{|c|}{ Total } \\
\hline & Freq & $\%$ & Freq & $\%$ & Freq & $\%$ & Freq & $\%$ & Freq & $\%$ & Count & Mean & SD & Median \\
\hline $\begin{array}{l}\text { I am not happy with the } \\
\text { economic condition of my } \\
\text { family }\end{array}$ & 0 & $.0 \%$ & 216 & $51.2 \%$ & 90 & $21.3 \%$ & 94 & $22.3 \%$ & 22 & $5.2 \%$ & 422 & 2.82 & .95 & 2.00 \\
\hline $\begin{array}{l}\text { I have the responsibility } \\
\text { for children's care }\end{array}$ & 0 & $.0 \%$ & 123 & $29.1 \%$ & 44 & $10.4 \%$ & 155 & $36.7 \%$ & 100 & $23.7 \%$ & 422 & 3.55 & 1.14 & 4.00 \\
\hline $\begin{array}{l}\text { I have responsibility for } \\
\text { Elders care }\end{array}$ & 0 & $.0 \%$ & 95 & $22.5 \%$ & 52 & $12.3 \%$ & 174 & $41.2 \%$ & 101 & $23.9 \%$ & 422 & 3.67 & 1.07 & 4.00 \\
\hline $\begin{array}{l}\text { My spouse/Partner's } \\
\text { demands interfere with } \\
\text { work-related activities }\end{array}$ & 0 & $.0 \%$ & 236 & $55.9 \%$ & 76 & $18.0 \%$ & 74 & $17.5 \%$ & 36 & $8.5 \%$ & 422 & 2.79 & 1.02 & 2.00 \\
\hline $\begin{array}{l}\text { I have to make changes in } \\
\text { family activities plans } \\
\text { due to my work-related } \\
\text { duties }\end{array}$ & 0 & $.0 \%$ & 90 & $21.3 \%$ & 76 & $18.0 \%$ & 198 & $46.9 \%$ & 58 & $13.7 \%$ & 422 & 3.53 & .98 & 4.00 \\
\hline $\begin{array}{l}\text { I do not have cordial } \\
\text { relation with my family }\end{array}$ & 0 & $.0 \%$ & 272 & $64.5 \%$ & 114 & $27.0 \%$ & 22 & $5.2 \%$ & 14 & $3.3 \%$ & 422 & 2.47 & .74 & 2.00 \\
\hline $\begin{array}{l}\text { Family-related strain } \\
\text { interferes with my ability } \\
\text { to perform job-related } \\
\text { duties }\end{array}$ & 0 & $.0 \%$ & 210 & $49.8 \%$ & 67 & $15.9 \%$ & 88 & $20.9 \%$ & 57 & $13.5 \%$ & 422 & 2.98 & 1.12 & 3.00 \\
\hline $\begin{array}{l}\text { My Children's future } \\
\text { bothers me }\end{array}$ & 0 & $.0 \%$ & 174 & $41.2 \%$ & 95 & $22.5 \%$ & 91 & $21.6 \%$ & 62 & $14.7 \%$ & 422 & 3.10 & 1.10 & 3.00 \\
\hline
\end{tabular}

Source: Primary source 
Overall respondents disagree that they are not happy with the economic condition of their family with the mean and standard deviation of $2.82 \pm .95$, that their spouse/partner's demands interfere with work-related activities with the mean and standard deviation of $2.79 \pm 1.02$, that they do not have cordial relation with their family with the mean and standard deviation of $2.47 \pm .74$, that their family-related strain interferes with their ability to perform job-related duties with the mean and standard deviation of $2.98 \pm 1.12$. Overall respondents agree that they have responsibility for children's care with the mean and standard deviation of $3.55 \pm 1.14$, that they have responsibility for elders care with the mean and standard deviation of $3.67 \pm 1.07$, that they have to make changes in family activities plans due to work-related duties with a mean and standard deviation of $3.53 \pm .98$ and that their children's future bothers them with the mean and standard deviation of $3.10 \pm 1.10$.

\section{b. Measuring Overall Challenges due to Family Factors}

To measure overall challenges due to family factors a score was obtained by summating scores of 8 components. The score ranges from $8-40$ and this range is divided equally. The level of challenges due to family factors is as follows. The score 8-18 the challenge is low; 19-29 level of challenge is moderate and 30-40 level of challenge is high. The analysis is given below:

Table 8: Overall challenge due to Family factors

\begin{tabular}{|c|c|c|c|c|}
\hline & Frequency & Percent & Mean & S.D \\
\hline Low & 29 & 6.9 & \multirow[t]{3}{*}{24.90} & \multirow[t]{3}{*}{4.97} \\
\hline Moderate & 290 & 68.7 & & \\
\hline$\overline{\text { High }}$ & 103 & 24.4 & & \\
\hline Total & 422 & 100.0 & & \\
\hline \multicolumn{5}{|c|}{ Level of Challenge: 8-40 } \\
\hline \multicolumn{2}{|c|}{$8-18$} & \multicolumn{3}{|c|}{ Low } \\
\hline \multicolumn{2}{|c|}{$19-29$} & \multicolumn{3}{|c|}{ Moderate } \\
\hline \multicolumn{2}{|c|}{$30-40$} & \multicolumn{3}{|c|}{ High } \\
\hline
\end{tabular}

Source: Primary source

$6.9 \%$ had low challenges due to family factors, $68.7 \%$ had moderate challenges due to family factors and $24.4 \%$ had high challenges due to family factors. Overall respondents had a moderate level of challenges due to family factors with mean and standard deviation score of $24.90 \pm 4.97$

\section{c. Testing the Hypothesis}

Correlation between challenges due to family factors and work-life balance. To ascertain the relationship between challenges due to family factors and work-life balance Karl Pearson correlation coefficient was calculated. Hypothesis $\mathrm{H}_{1} 1(\mathrm{~b})$ : There is a relationship between challenges due to family factors and work-life balance is tested.

Table 9: Correlation between challenges due to Family factors and Work-life balance

\begin{tabular}{|c|l|c|c|c|}
\hline \multicolumn{5}{|c|}{ Correlations } \\
\hline & & Pearson Correlation & $\mathrm{p}$ & \\
\hline WLB & Overall Challenge due to Family Factors & -.344 & .000 & $\mathrm{sig}$ \\
\hline
\end{tabular}

Source: Primary

The above table shows that there is a significant negative correlation between challenges due to family factors and work-life balance with $\mathrm{r}=-.344, \mathrm{p}=.000$ which is $<0.01$. Therefore, hypothesis $\mathrm{H}_{1} 1(\mathrm{~b})$ : There is a relationship between challenges due to family factors, and work-life balance is accepted. So, we conclude that the lesser the challenge higher is the work-life balance. 


\section{d. Regression Analysis: Impact of Family Factors on Work-Life Balance}

To evaluate the impact of components on work-life balance backward regression analysis was performed by taking 8 components as the independent variable and work-life balance as a dependent variable.

Table 10: Components of Family Factors and WLB: Regression Analysis

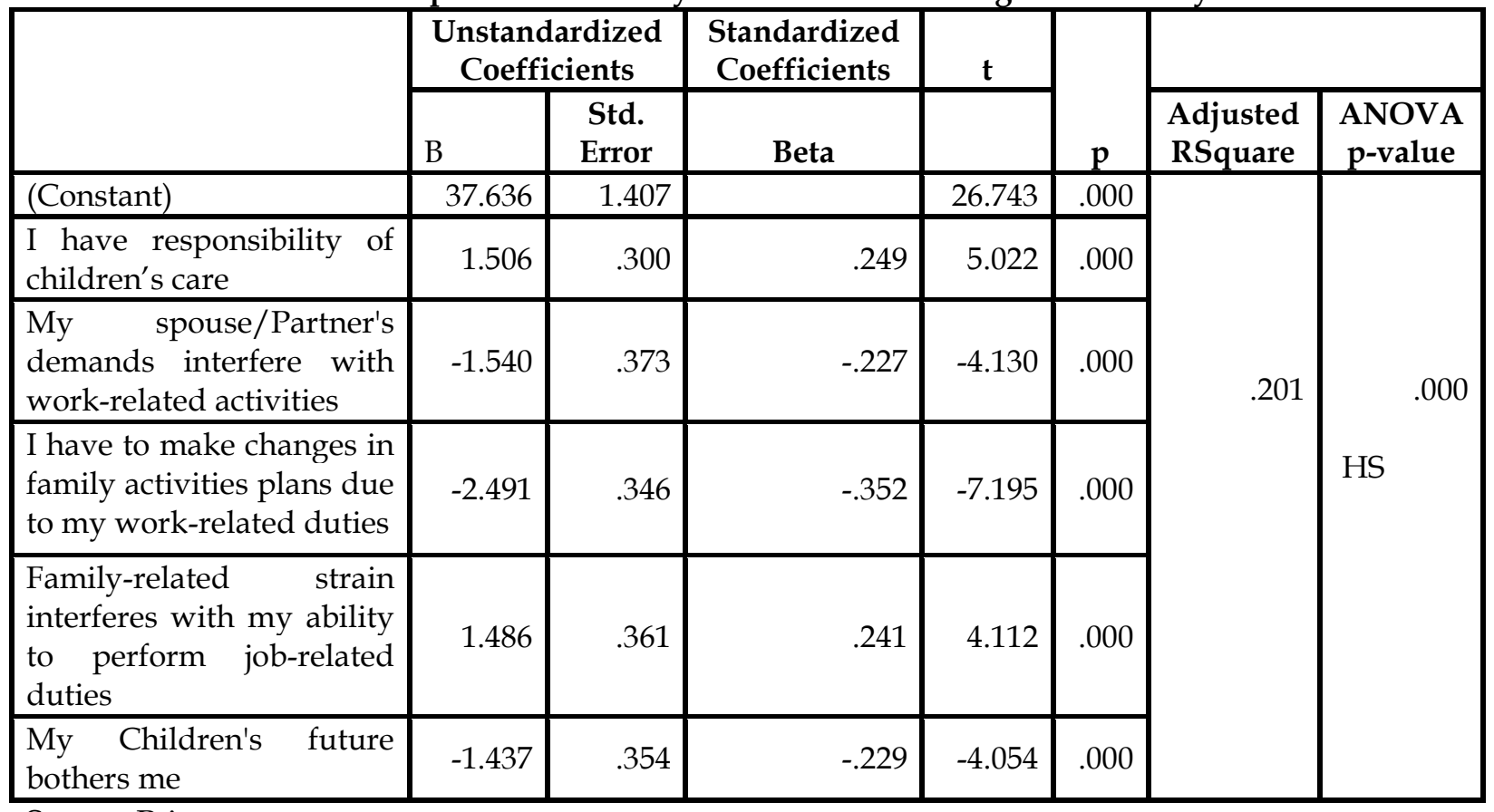

Source: Primary

Among 8 components backward regression analysis resulted in 5 significant components affecting work-life balance. They are "I have the responsibility of children's care" with $\beta=.249$, "My spouse/Partner's demands interfere with work-related activities" with $\beta=-.227$, "I have to make changes in family activities plans due to my work-related duties" with $\beta=-.352$, "Family-related strain interferes with my ability to perform job-related duties" with $\beta=.241$, "My Children's future bothers me" with $\beta=-.229$. Among these "My spouse/Partner's demands interfere with work-related activities", I have to make changes in family activities plans due to my work-related duties", "My Children's future bothers me" have a negative impact on work-life balance which means these factors lead low work-life balance. Factors such as "I have the responsibility of children's care "and "Familyrelated strain interferes with my ability to perform job-related duties "have a positive impact on work-life balance which means this leads to higher work-life balance. All these components have a $20.1 \%$ influence on work-life balance.

\subsection{Organizational Factors}

$\mathrm{H}_{1} 1$ (c): There is a relationship between challenges due to Organizational factors and Work-life Balance is tested here. Work-life balance is not just the responsibility of the employees but also of the employers. Organizations that cater to the needs of the employees provide policies and programs that help the employees in maintaining a work-life balance. Organizational factors such as family-friendly policies, relationships with the superior, relationship with colleagues, work schedule, commitments other than teaching, infrastructure facilities influence work-life balance.

\section{a. Assessment of Challenges due to Organizational Factors on Work-life balance}

Challenges due to organizational factors were measured using 6 questions and these questions were measured on 5-point rating scale strongly Disagree(SD) (1), Disagree(D) (2), Neutral(N) (3), Agree(A)(4), Strongly Agree(SA) (5). Interpretation will be done based on the Mean Value as $<2=S D$, $<3=\mathrm{D},>3 \mathrm{~A}$ and $>4=\mathrm{SA}$. 
Table 11: Challenges due to Organizational factors on Work-life balance

\begin{tabular}{|c|c|c|c|c|c|c|c|c|c|c|c|c|c|c|}
\hline & \multicolumn{2}{|c|}{ SD } & \multicolumn{2}{|c|}{ D } & \multicolumn{2}{|c|}{$\mathrm{N}$} & \multicolumn{2}{|c|}{ A } & \multicolumn{2}{|c|}{ SA } & \multicolumn{4}{|c|}{ Total } \\
\hline & Fre & $\%$ & Fre & $\%$ & Fre & $\%$ & Fre & $\%$ & Fre & $\%$ & Count & Mean & \begin{tabular}{|l|} 
Standard \\
Deviation
\end{tabular} & Median \\
\hline $\begin{array}{l}\text { My organization } \\
\text { does not provide } \\
\text { family-friendly } \\
\text { policies to fulfill } \\
\text { family } \\
\text { commitments }\end{array}$ & 0 & $.0 \%$ & 129 & $30.6 \%$ & 105 & $24.9 \%$ & 131 & $31.0 \%$ & 57 & $13.5 \%$ & 422 & 3.27 & 1.04 & 3.00 \\
\hline $\begin{array}{lr}\text { I do not have a } \\
\text { good relation } \\
\text { with } \\
\text { colleagues }\end{array}$ & 0 & $.0 \%$ & 318 & $75.4 \%$ & 59 & $14.0 \%$ & 32 & $7.6 \%$ & 13 & $3.1 \%$ & 422 & 2.38 & .76 & 2.00 \\
\hline $\begin{array}{l}\text { My organization } \\
\text { does not follow a } \\
\text { flexible work } \\
\text { schedule }\end{array}$ & 0 & $.0 \%$ & 134 & $31.8 \%$ & 105 & $24.9 \%$ & 133 & $31.5 \%$ & 50 & $11.8 \%$ & 422 & 3.23 & 1.03 & 3.00 \\
\hline $\begin{array}{l}\text { My organization } \\
\text { does not provide } \\
\text { adequate } \\
\text { Infrastructure } \\
\text { facilities }\end{array}$ & 0 & $.0 \%$ & 185 & $43.8 \%$ & 110 & $26.1 \%$ & 61 & $14.5 \%$ & 66 & $15.6 \%$ & 422 & 3.02 & 1.10 & 3.00 \\
\hline
\end{tabular}

Source: Primary source 
Overall respondents agree that their organization does not provide family-friendly policies to fulfill their family commitments with the mean and standard deviation of $3.27 \pm 1.04$, that their organization does not follow a flexible work schedule with the mean and standard deviation of $3.23 \pm 1.03$, that they have been given too many other tasks/commitments other than teaching with the mean and standard deviation of $3.59 \pm 1.00$, that their organization does not provide adequate infrastructure facilities with the mean and standard deviation of $3.02 \pm 1.10$. Whereas Overall respondents disagree that they do not have a good relationship with their superior with the mean and standard deviation of $2.43 \pm .73$, that they do not have a good relationship with their colleagues with the mean and standard deviation of $2.38 \pm .76$.

\section{b. Measuring Overall Challenges due to Organizational factors}

To measure overall challenges due to organizational factors a score was obtained by summating scores of 6 components. The score ranges from $6-30$ and this range is divided equally. The level of challenges due to organizational factors is as follows. The score 8-18 challenge low, 19-29 level of challenges moderate, and 30-40 level of challenge are high. The analysis is given below:

Table 12: Overall challenge due to Organizational Factors

\begin{tabular}{|c|c|c|c|c|}
\hline & Frequency & Percent & Mean & S.D \\
\hline Low & 85 & 20.1 & \multirow[t]{3}{*}{17.94} & \multirow[t]{3}{*}{3.73} \\
\hline Moderate & 299 & 70.9 & & \\
\hline High & 38 & 9.0 & & \\
\hline Total & 422 & 100.0 & & \\
\hline \multicolumn{5}{|c|}{ Level of Challenge: $6-30$} \\
\hline \multicolumn{2}{|c|}{$6-14$} & \multicolumn{3}{|c|}{ Low } \\
\hline \multicolumn{2}{|c|}{$15-22$} & \multicolumn{3}{|c|}{ Moderate } \\
\hline \multicolumn{2}{|c|}{$23-30$} & \multicolumn{3}{|c|}{ High } \\
\hline
\end{tabular}

Source: Primary

$20.1 \%$ had low challenges due to Organizational factors, $70.9 \%$ had moderate challenges due to Organizational factors and $9.0 \%$ had high challenges due to Organizational factors. Overall respondents had a moderate level of challenges due to Organizational factors with mean and standard deviation score of $17.94 \pm 3.73$

\section{c. Testing the Hypothesis}

Correlation between challenges due to Organizational factors and work-life balance. To ascertain the relationship between challenges due to Organizational factors and work-life balance Karl Pearson correlation coefficient was calculated. Hypothesis $\mathrm{H}_{1} 2 \mathrm{c}$ : There is a relationship between challenges due to Organizational factors and work-life balance is tested.

Table 13: Correlation between challenges due to Organizational factors and Work-life balance

\begin{tabular}{|c|c|c|c|c|}
\hline \multicolumn{5}{|c|}{ Correlations } \\
\hline & & Pearson Correlation & p & \\
\hline WLB & Overall Challenge due to Organizational Factors & -.336 & .000 & sig \\
\hline
\end{tabular}

Source: Primary

The above table shows that there is a significant negative correlation between challenges due to Organizational factors and work-life balance with $r=-.336, p=.000$ i.e $<0.01$. Therefore, hypothesis $\mathrm{H}_{1} 1$ (c): There is a relationship between challenges due to Organizational factors, and work-life balance is accepted. So, we conclude that the lesser the challenge higher is the work-life balance. 


\section{d. Regression Analysis: Impact of Family Factors on Work-Life Balance}

To evaluate the impact of these components on work-life balance backward regression analysis was performed by taking 6 components as the independent variables and work-life balance as a dependent variable.

Table 14: Components of Organization Factors and WLB: Regression Analysis

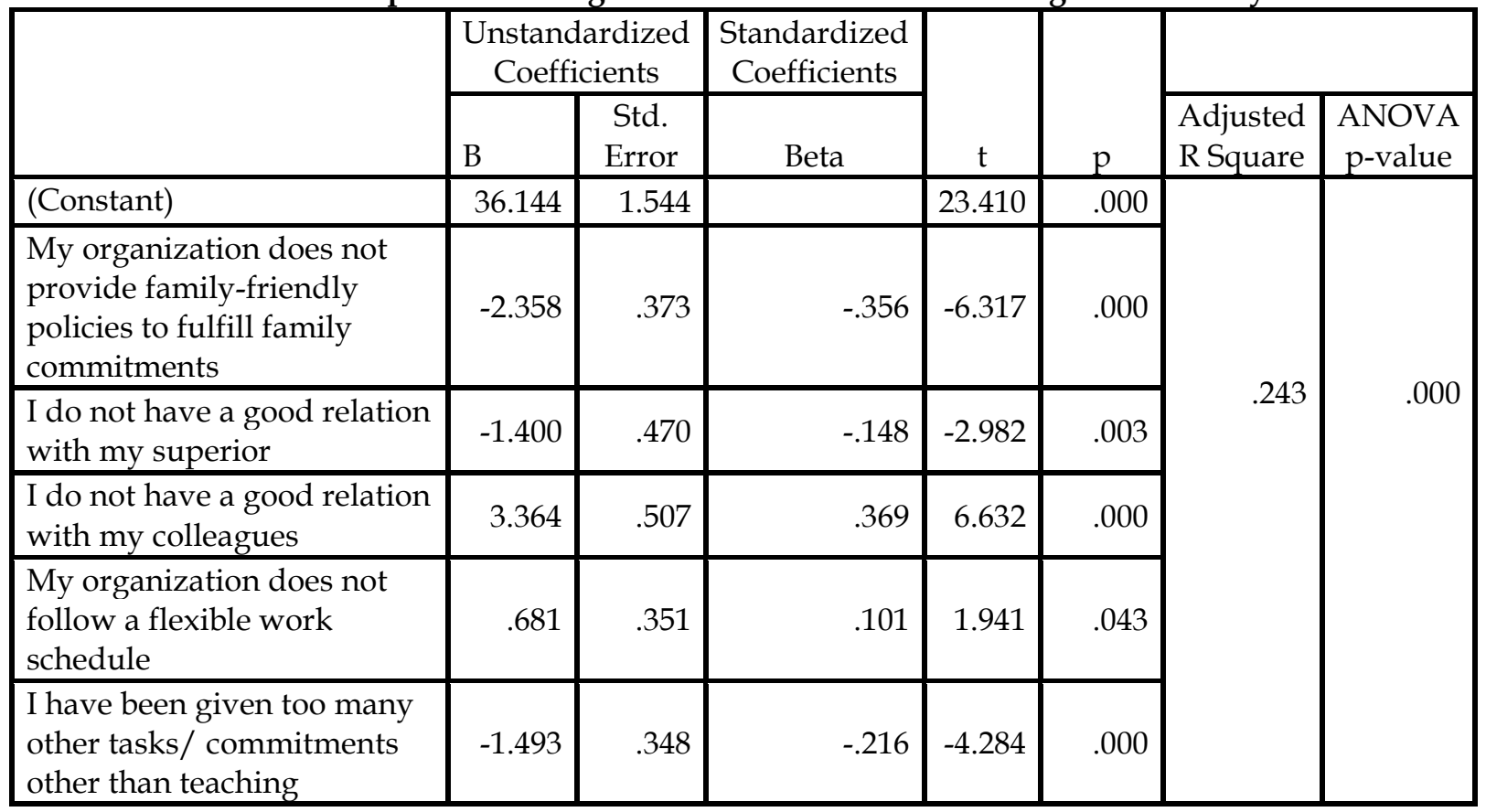

Source: Primary

Among these 6 components backward regression analysis resulted in 5 significant components affecting work-life balance. They are "My organization does not provide family-friendly policies to fulfill family commitments" with $\beta=-.356$, "I do not have a good relationship with my superior" with $\beta=-.148$, "I do not have a good relation with my colleagues" with $\beta=.369$, "My organization does not follow flexible work schedule" with $\beta=.101$, "I have been given too many other tasks/ commitments other than teaching" with $\beta=-.216$. Among these "My organization does not provide family-friendly policies to fulfill family commitments", "I do not have a good relationship with my superior", and "I have been given too many other tasks/commitments other than teaching" have a negative impact on work-life balance which means these factors lead low work-life balance. Factors such as, "I do not have a good relation with my colleagues" and "My organization does not follow flexible work schedule" have a positive impact on work-life balance which means this will lead to a higher work-life balance. All these components have a $24.3 \%$ influence on work-life balance.

\section{Discussion}

Interpretation of the data regarding the Challenges such as Individual, Family, and Organizational faced by Women teachers of State Universities of Karnataka has been done in this paper. Study shows Challenges due to Individual Factors, Family Factors, and Organizational Factors are found to be Moderate. 


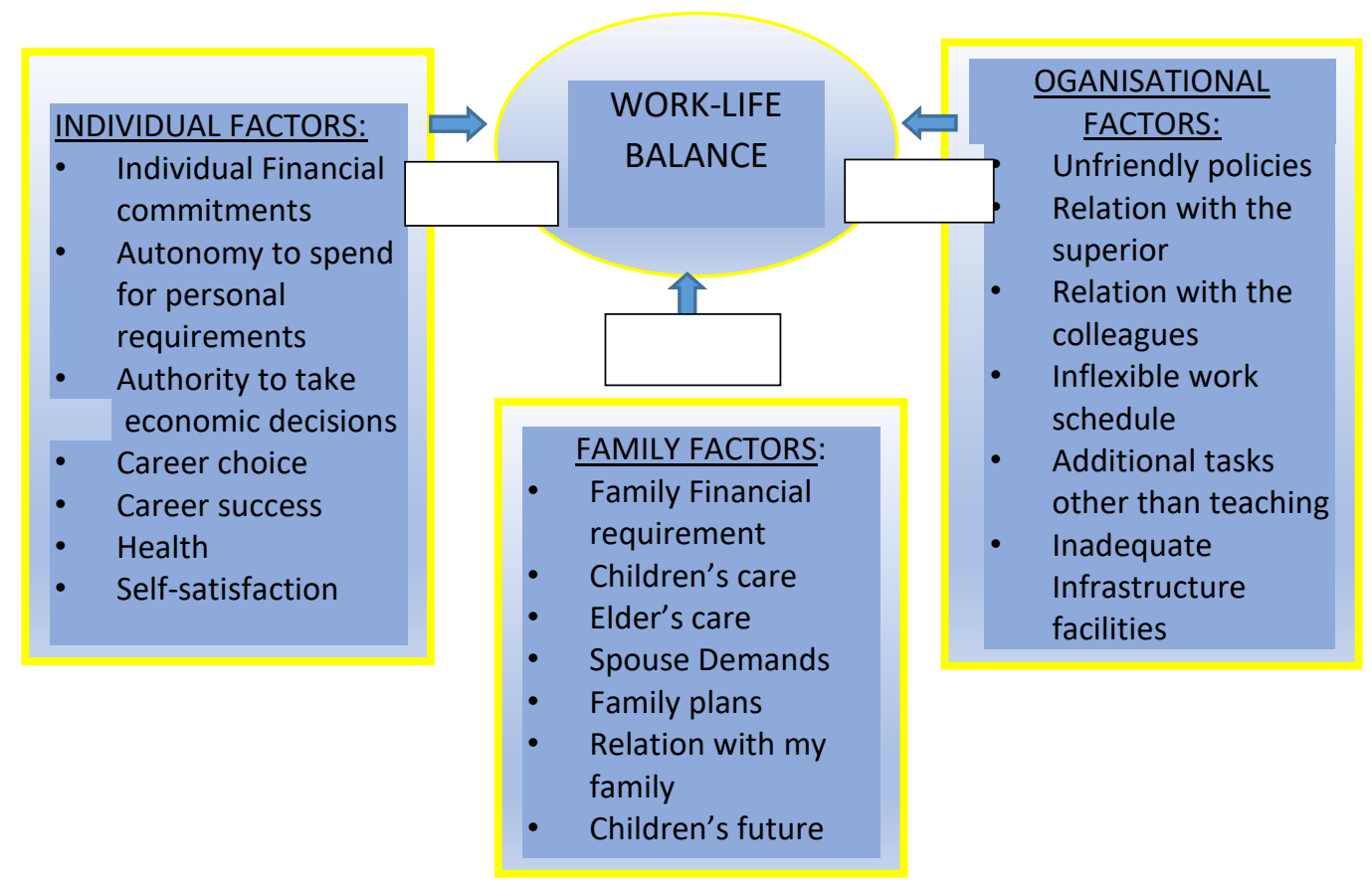

Figure 1: Challenges Faced by Women teachers of State Universities of Karnataka

Karl Pearson's correlation coefficient test shows that there is a negative significant correlation between Individual Factors ( $-.229, \mathrm{p}=.000)$, Family factors $(-.344, \mathrm{p}=.000)$, Organizational factors ($.336, \mathrm{p}=.000)$ and work-life balance. This shows that the higher the challenges due to Individual factors, Family Factors, and Organizational factors, the lower is the work-life balance.

\section{Suggestions:}

Counselor ought to be designated by the Organization for seeing increasing issues of Working Women. Administrators need to make an atmosphere where representatives don't fear raising a family. Supervisors can give a steady domain that grants adaptability in plans, working from home choices, individual downtime, on-location kid care, and other family-engaged programmes. Inner informal organization (discussion, blog, tutor, mentors) for working guardians. Thus, associations need to detail rules for the administration of WFCs since they are identified with the work fulfillment and performance of the employees. Further the exploration ought to be led on unskilled individuals. Extra research is likewise expected to look at the two people since encounters might vary as to work and family adjusts and furthermore discovers more results of work and family struggle. So as to achieve top to bottom comprehension of one's work and family life, scientists need to ponder numerous points of view, for example, work pressure, personal satisfaction, emotional wellness, and work request.

\section{Conclusion:}

According to the study in the first research question of challenges faced by women employees Overall respondents had a moderate level of a challenge due to individual factors (Mean score 24.16 out of 40), Family factors(Mean score 24.90 out of 40 ) and Organizational factors (Mean score 17.94 out of 30 ) and a significant negative correlation between challenges due to individual factors $(r=-.229, p=$ $.000)$, Family factors $(\mathrm{r}=-.344, \mathrm{p}=.000)$ and Organizational factors $(\mathrm{r}=-.336, \mathrm{p}=.000)$ and work-life balance. The issue of Work-Life balance should be taken into consideration and dealt with by the business and the relatives of a woman as her business is clearly or by suggestion profitable to all of them. A woman with a healthy lifestyle can have greater satisfaction and gainfulness, extraordinary prosperity, fewer absents at work, will end up being increasingly brief, steadfast, and self-influenced. 


\section{References:}

[1]. Greenhaus, J. H., Allen, T. D., \& Spector, P. E. (2006). Health consequences of work-family conflict: The dark side of the work-family interface. In P. L. Perrewe\& D. C. Ganster (Eds.), Research in occupational stress and well-being, 5(2), 61-99. Oxford, UK: JAI Press/Elsevier.

[2]. Clark, S.C. (2000). Work/family border theory: A new theory of work/family balance, Human Relations, 53(6), 747-770.

[3]. Parkes, L.P. and Langford, P.H. (2008), Work-life balance or work-life alignment? A test of the importance of work-life balance for employee engagement and intention to stay in organizations, Journal of Management \& Organization. 14(3). 267-284. DOI: https://doi.org/10.1017 /S1833367200003278

[4]. Anitha, R., \&Muralidharan, D. (2014). A Study on the influence of Demographic and work-related aspects on the work life balance of marketing Professional. Global Journal for Research Analysis. 3(11), 100-102.

[5]. Darji, Mittal. (2016). The challenges faced by Indian working women to balance professional and social life in $21^{\text {st }}$ century, International Conference women in Science and Technology: Creating sustainable Career. 1(1). 60-66.

[6]. Delina, G. and R. Prabhakara Raya (2013), "A study on Work-Life Balance in Working Women", IRACST - International Journal of Commerce, Business and Management (IJCBM), ISSN: 2319-2828, 2(5)

[7]. Rani Rinku, (2013) “Marital Adjustment Problems of Working and Non-Working Women in Contrast of Their Husband", International Journal for Research in Education, (IJRE) ISSN: 2320-091, 2(7).

[8]. Noronha, Delrose, Sonia; \&Aithal, P.S. (2019), Work-Life Balance and Glass Ceiling of Women Employees- A Literature review, Saudi Journal of Business and Management Studies, ISSN: 2415-6663, 4(5): 386-396

[9]. Martin, E. (2001). The woman in the body: A cultural analysis of reproduction. Beacon Press.

[10]. Dube, L. (2001). Anthropological explorations in gender: Intersecting fields. New Delhi: Sage Publications Pvt. Limit

[11]. Andal, N. (2002). Women and Indian society: Options and constraints. New Delhi: Rawat Publications. Arnove, R. F., Torres, C. A., \& Franz, S. (Eds.). (2012). Comparative education: The dialectic of the global and the local. Rowman \& Littlefield Publishers.

[12]. Deglado, Enilda\&Canabal, Maria (2006), Factors associated with Negative spill over from Job to home among Latinos in the United states, Journal of Family and economic issues.27(2): 92-112

[13]. Eagly, Alice \& Carli Linda (2007), Through the Labyrinth: The truth about how women become leaders, Harvard Business Press

[14]. Noronha, Delrose, Sonia; \&Aithal, P.S. (2017), Organizational Strategic approach towards Work-Life Balance of Women in India, International Journal of Management, Technology and social sciences, ISSN: 2581-6012, 2(1): 19-24

[15]. Noronha, S., \&Aithal, P. (2016). Glass Ceiling- A Silent Barrier for Women in Highly Advanced and Humanistic Society. IRA-International Journal of Management \& Social Sciences (ISSN 2455-2267), 5(3), 455-466. doi: http:/ / dx.doi.org/10.21013/jmss.v5.n3.p9

[16]. Noronha, S., \&Aithal, P. (2019). Influence of socio-Demographic factors on Work-life balance (WLB) among Public Universities teachers in Karnataka, International Journal of Scientific Research, 8(11): 2277- 2281

[17]. Noronha, Sonia Delrose and Aithal, P.S. (2019), Work-Life balance among Women Employees: A study on initiatives undertaken by Indian Organizations, MERC Global's International Journal of Management, 7(1): 22-27.

[18]. Noronha, Sonia Delrose and Aithal, P.S. and Pradeep, M.D, (2017), Study on Policy framework towards Work Life balance in India, 3(2): 11-16.

[19]. https://www.ugc.ac.in/stateuniversity.aspx retrieved on...12.5.2019@2.33 pm

[20]. Tavakol, Mohsen; Reg Dennick. (2011), Making sense of Cronbach's Alpha, Indian Journal of Medical Education, ISSN: 2014-6372, 2:53-55 